\title{
Antioxidant compound from the Lycopersicon esculentum
}

\author{
Hyoung-Geun Kim ${ }^{1} \cdot$ Hyeong-Ju Jeon ${ }^{2}$ (D)

\section{토마토(Lycopersicon esculentum)로부터 GSH 회복능을 보이는 항산화 화합물의 분리 동정}

\author{
김형근 ${ }^{1} \cdot$ 전형주 $^{2}$
}

Received: 17 September 2020 / Accepted: 7 October 2020 / Published Online: 31 December 2020

(C) The Korean Society for Applied Biological Chemistry 2020

\begin{abstract}
The liquids of Lycopersicon esculentum were extracted with $70 \%$ aqueous $\mathrm{MeOH}$ and the concentrates were partitioned into EtOAc, $n$-BuOH, and $\mathrm{H}_{2} \mathrm{O}$ fractions. The repeated silica gel and octadecyl silica gel column chromatographies for the EtOAc fraction, whose activity was confirmed, led to isolation of one flavonol compound. The chemical structures of the compound were determined as quercetin (1) based on spectroscopic analyses including nuclear magnetic resornance, infrarad spectroscopy, and mass spectroscopy. Through this study, the antioxidant efficacy was confirmed by demonstrating that the L. esculentum fraction showing an increase in glutathione mean (GM) and a decrease in glutathione heterogeneity $(\mathrm{GH})$ uniformly raises the intracellular glutathione (GSH) level.
\end{abstract}

Keywords Flavonol Glutathione recovery $\cdot$ Lycopersicon esculentum - Nuclear magnetic resornance $\cdot$ Quercetin

Hyeong-Ju Jeon $(\square)$

E-mail: befree5007@hanmail.net

${ }^{1}$ Graduate School of Biotechnology and Department of Oriental Medicinal Biotechnology, Kyung Hee University, Yongin 17104, Republic of Korea

${ }^{2}$ Department of Food \& Nutrition, Jangan University, Hwaseong, Gyeonggi 18331, Republic of Korea

This is an Open Access article distributed under the terms of the Creative Commons Attribution Non-Commercial License (http://creativecommons. org/licenses/by-nc/3.0/) which permits unrestricted non-commercial use, distribution, and reproduction in any medium, provided the original work is properly cited.

\section{서 론}

토마토(Lycopersicon esculentum)는 가지과의 한해살이풀로, 키 는 1-1.5 $\mathrm{m}$ 정도이며 가지를 많이 내고 부드러운 흰 털이 난다. 작은 잎은 9-19개 정도로 달걀 모양이나 긴 타원 모양이며 끝 이 뾰족하고 깊이 패어 들어간 톱니가 있다. 꽃은 5-8월에 노 란색으로 피고 열매는 6 월부터 붉게 읽는다. 햇볕을 받아 빨강 게 익는 노지 재배 토마토는 vitamin $\mathrm{C}, \beta$-carotene, vitamin $\mathrm{B}$ 군, vitamin $\mathrm{E}$ 등의 항산화 비타민이 풍부 하다. 붉은색 색소 성분인 lycopene 은 carotenoid 의 일종으로, $\beta$-carotene 이상의 항산력이 있어서 암이나 동맥경화 등을 예방하는 효과가 있는 것으로 알려져 있으며[1], 10대 장수식품 중 하나로 꼽힌다. 주 요성분으로는 adenine, trigonelline, choline 및 소량의 tomatine 이 분리 보고되어 있다[2]. 최근 식물에서 얻어지는 다양한 유 용성분들은 anticancer, antimicrobial, antivirus, anti-aging 등의 다양한 생리활성을 지니고 있으며 의약품, 식품, 화장품 외에 다양한 분야에 이용되고 있다. 토마토는 여러 생리활성 물질들 을 함유하고 있으며 그 결과 다양한 질병의 예방을 갖는 것으 로 보고되었다. 하지만 현재까지 antioxidant 및 anti-aging 효과 를 통한 화장품 소재로서의 가능성에 대한 연구 결과는 보고된 바가 없다.

글루타치온(glutathione, GSH)은 세포 손상을 야기하는 reactive oxygen species (ROS)에 대한 세포 방어 기전에서 중 심적인 역할을 한다[1]. GSH는 글루타치온 과산화효소 (glutathione peroxidase)에 의해 ROS에 전자를 전달하고, $\mathrm{GSH}$ 는 산화 형태인 glutathione disulphide (GSSG)을 형성한다. 또 한, GSSG는 glutathione reductase 에 의해 $\mathrm{NADPH}$ 를 사용하 여 $\mathrm{GSH}$ 로 다시 환원되면서 활성산소로부터 세포를 보호한다 [2,3]. $\mathrm{GSH}$ 는 세포질에서 생산되어 $\mathrm{GSH}$ 산화환원이 필요한 미 토콘드리아 또는 핵과 같은 세포 내 소기관으로 전달되며, $\mathrm{GSH}$ 농도 유지는 세포에서 산화환원 능력과 신호 전달 체계의 중요 
한 지표가 된다. 세포 내 GSH 농도가 높을수록 산화적 스트레 스로부터 세포를 보호할 수 있고, 노화성 질병을 방지할 수 있 다[4].

최근 살아있는 세포 내 $\mathrm{GSH}$ 농도를 측정할 수 있는 FreSHtracer라는 가역성 프로브를 개발했다[5]. 살아있는 세포에 서의 항산화능을 측정할 수 있는 프로브는 현재까지 개발된 적 이 없는 것으로, 기존의 화학적 기법인 라디칼 소거능 평가 실 험과 달리 FreSHtracer가 세포막을 통과하여 세포 내 $\mathrm{GSH}$ 의 thiol과 반응할 수 있기 때문에 실시간으로 세포 내 GSH 농도 와 회복능을 확인할 수 있다. FreSHtracer는 $580 \mathrm{~nm}$ 에서 형광 방출 스펙트럼을 가지고(F580), GSH의 thiol과 반응하여 510 $\mathrm{nm}$ 의 형광으로 변하게 된다(F510). 이 때 F510/F580의 상대적 인 비율을 구함으로써 $\mathrm{GSH}$ 양의 변화를 측정한다. 본 연구에 서는 F510/F580 비율을 이용하여 세포 내 GSH의 평균값 (Glutathione mean, $\mathrm{GM}$ )과 세포간 $\mathrm{GSH}$ 의 분포양상(Glutathione heterogeneity, $\mathrm{GH})$ 을 측정할 수 있는 분석 방법을 개발했다. $\mathrm{GM}$ 은 F510/F580 비율의 평균값을 계산하여 측정할 수 있으며, $\mathrm{GH}$ 는 F510/F580 비율값의 표준편차를 평균에 대한 백분율로 계산하여 얻을 수 있다. 일반적으로 노화가 진행되었거나 산화 적 스트레스가 축적되어 기능이 저하된 세포는 세포 내 $\mathrm{GM}$ 값 이 낮아져 있으며, 세포간 $\mathrm{GSH}$ 의 분포가 매우 다양해져 $\mathrm{GH}$ 값 이 증가하는 경향을 보인다. 이것으로 세포의 항산화능을 객관 화할 수 있을 뿐만 아니라 세포의 품질을 측정할 수 있다. 또 한, 이 방법을 이용하여 항산화 기능을 가지는 물질의 효능 평 가에도 활용할 수 있다. 따라서 항산화 기능을 가진다고 잘 알 려진 토마토에서 얻어진 추출물과 분획물에 대해 $\mathrm{GSH}$ 항산화 효과를 확인하였고, 그 주요성분을 분리 동정하였다.

\section{재료 및 방법}

\section{실험 재료}

본 실험에서는 2019년 6월 셀투인에서 제공된 토마토(Lycopersicon esculentum)를 실험 재료로 사용하였다. 표품은 경희대학교 피 부생명공학센터 천연물화학 실험실(KHU-1906)에 보관되어 있다.

\section{기기 및 시약}

Column chromatography용 silica gel은 silica gel 60 (63-200 $\mu \mathrm{m})$ (Merck, Darmstadt, Germany)을 사용하였고, thin layer chromatography (이하 TLC라고 함)는 silica gel $60 \quad \mathrm{~F}_{254}$ (Merck, Darmstadt, Germany)를 사용하였다. NMR은 400 MHz FT-NMR spectrometer (Varian Inova AS 400, Varian, Palo Alto, CA, USA)로 측정하였고, infrarad (IR) spectrum은 Perkin model 599B (Perkin-Elmer, Waltham, MA, USA)로 측정하였다. UV는 Spectroline (Model ENF-240 C/F, Spectronics Corporation, Westbury, NY, USA)을 사용하였으며, 융점은 Fisher-Johns 융점측정기(Fisher Scientific, Miami, FL, USA)를 사용하여 측정하였고, 미보정하였다.

\section{GSH 회복능을 이용한 항산화능 평가}

$\mathrm{GSH}$ 회복능 측정은 미토콘드리아 내의 $\mathrm{GSH}$ 와 반응하는 MitoFreSHtracer probe (M-377, Cell2in, Seoul, Korea)를 이용

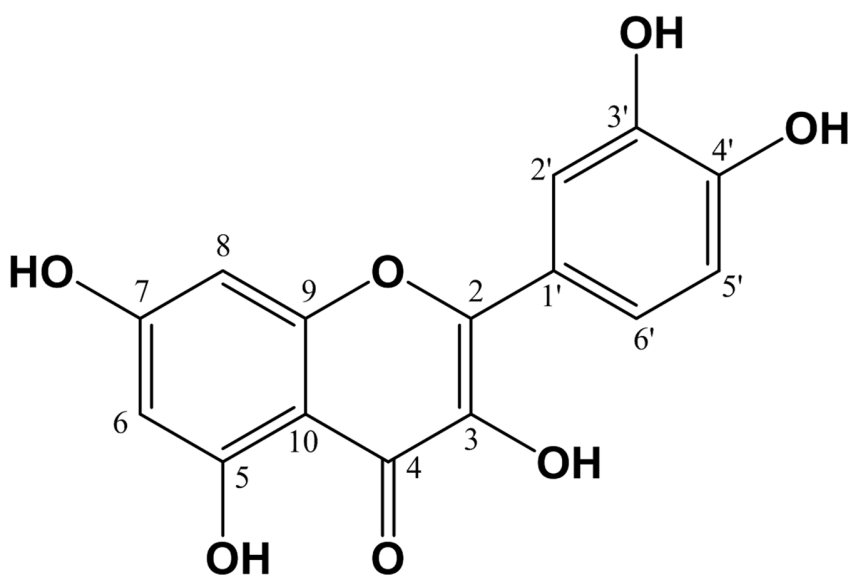

Fig. 1 Chemical structure of compound 1 from the Lycopersicon esculentum

하여 측정하였다[6]. 사용된 세포는 인간의 탯줄 유래 중간엽줄 기세포(Human umbilical cord-derived mesenchymal stem cell, $\mathrm{hUC}-\mathrm{MSC}$ ) passage number 15로, 분열과 성장이 더딘 노화 상태의 세포이다. 이 세포를 96 well optically clear bottom plate (6055300, PerkinElmer, Waltham, MA, USA)에 $3 \times 10^{4}$ cells $/ \mathrm{mL}$ 로 $100 \mu \mathrm{L}$ 씩 분주하고 24시간 동안 $10 \%$ fetal bovine serum (16000044, Gibco, Thermo Fisher Scientific, Waltham, MA, USA)+1\% penicillin-streptomycin (15140122, Gibco, Thermo Fisher Scientific, Waltham, MA, USA)가 든 Minimum Essential Medium $\alpha$ (12561056, Gibco, Thermo Fisher Scientific, Waltham, $\mathrm{MA}, \mathrm{USA})$ 조건에서 배양한 후 토마토 추출물을 첨가한 배지 를 농도별 $(5,10,20 \mu \mathrm{g} / \mathrm{mL})$ 로 제조한 후 세포에 처리하고 24 시간동안 배양하였다. 24시간 후 배지를 제거하고 Hank's Balanced Salt Solution (HBSS, LB 003-02, WELGENE, Gyeongsan, Korea)로 2회 세척하여 남아있는 성분을 최대한 제거했다. 그런 다음, $15 \mu \mathrm{M}$ MitoFreSHtracer로 1 시간 동안 $37^{\circ} \mathrm{C}$ 에서 염색했 다. 1시간 후 MitoFreSHtracer를 제거하고, HBSS $100 \mu \mathrm{L}$ 를 넣 은 채로 operetta high-content imaging system (HH12000000, PerkinElmer, Waltham, MA, USA)을 사용하여 $510 \mathrm{~nm}$ 와 580 $\mathrm{nm}$ 에서의 형광 intensity를 측정하였다. 추출물을 처리하지 않은 대조군의 $\mathrm{GM}, \mathrm{GH}$ 값을 기준으로 추출물에 의해 달라진 $\mathrm{GM}$, $\mathrm{GH}$ 값을 비교하여 $\mathrm{GSH}$ 회복능을 확인하였다. 실험결과는 각각 의 시료에 대한 $\mathrm{Mean} \pm \mathrm{SEM}$ 으로 나타내었으며, 통계분석에 의 한 유의성 검증은 Graph Pad Prism (Graph Pad Software, San Diego, CA, USA)을 이용하여 one-way ANOVA 분석을 시행하였다.

\section{활성물질의 분리}

토마토(Lycopersicon esculentum) 액상 $4 \mathrm{~kg}$ 을 $70 \% \mathrm{MeOH}$ 수 용액 $(68 \mathrm{~L} \times 4)$ 으로 두 차례 걸쳐 추출한 후 여과지로 여과를 하 였다. 얻어진 여액을 $45^{\circ} \mathrm{C}$ 에서 감압농축하고, 이 농축물을 물 과 ethyl acetate로 분배 추출하였으며, 물층은 다시 $n$-butanol로 분배 추출 하였다. 각 층을 감압농축하여 EtOAc (TME, $120 \mathrm{~g}$ ), $n$ - $\mathrm{BuOH}\left(\mathrm{TMB}, 245 \mathrm{~g}\right.$ ) 및 $\mathrm{H}_{2} \mathrm{O}$ (TMW, $545 \mathrm{~g}$ ) 분획을 얻었다. $\mathrm{TME}$ 분획 $(120 \mathrm{~g})$ 에 대하여 silica gel $\left(\mathrm{SiO}_{2}\right)$ column chromatography 
GM

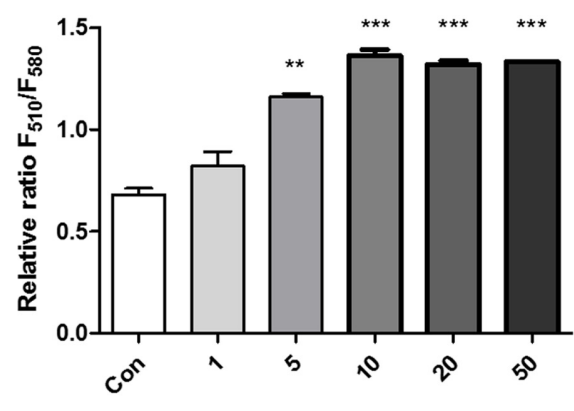

tomato extract (Lycobeads $\circledast)$ ) $(\mu \mathrm{g} / \mathrm{mL}$ )
GH

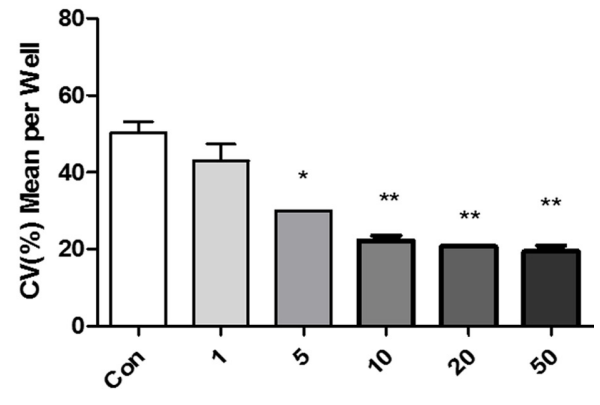

tomato extract (Lycobeads $®)(\mu \mathrm{g} / \mathrm{mL})$

Fig. 2 Evaluation of antioxidative activity using GM and GH after treatment with extracts of tomato (Lycobeads ${ }^{\circledR}$ ). GSH recovery capacity assay of tomato was performed in concentration dependent manner. Results are presented as mean \pm SEM. $* p \leq 0.05, * * p \leq 0.01, * * * p \leq 0.001$ compared with control. Con: non-treated (control) group

(A)

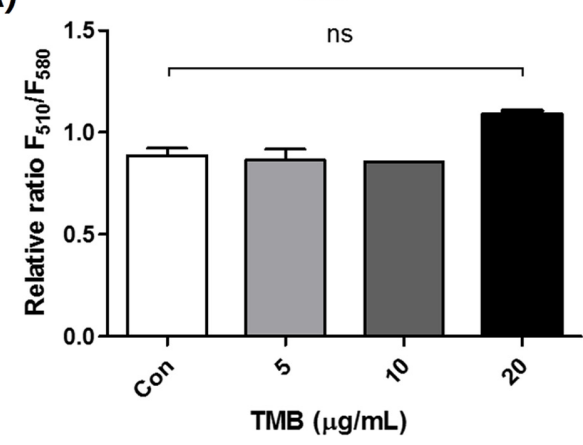

(B)

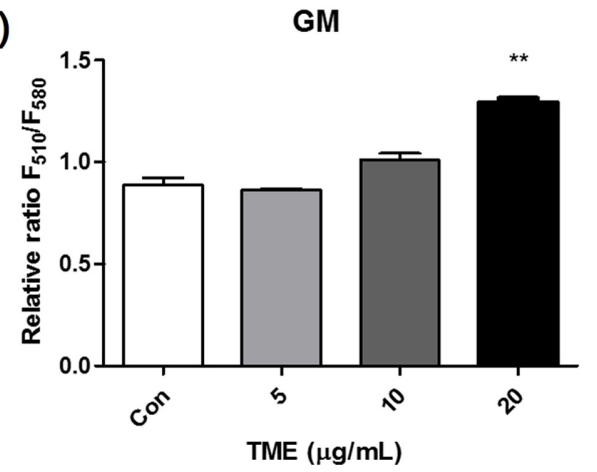

GH

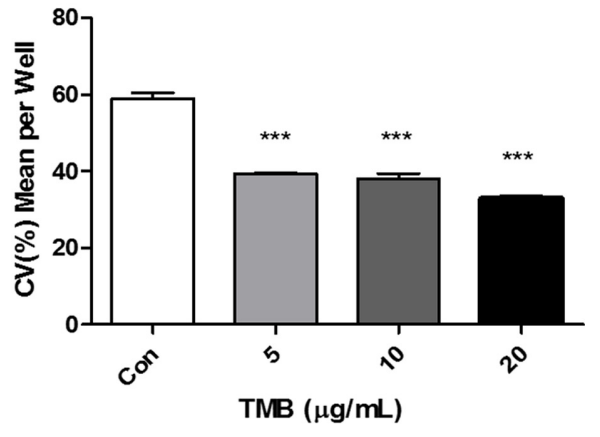

GH

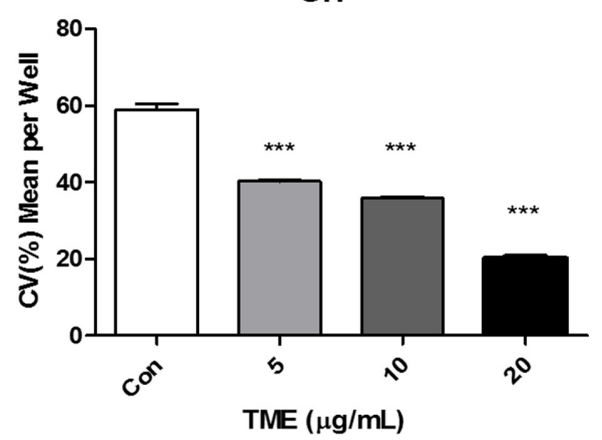

Fig. 3 Evaluation of antioxidative activity using GM and GH after treatment with EtOAc (TME) and $n$-BuOH (TMB) fractions from tomato extract. GSH recovery capacity assay of TME and TMB were performed in concentration dependent manner. Results are presented as mean \pm SEM. $* * p \leq 0.01$, $* * * p \leq 0.001$ compared with control. Con: non-treated (control) group

(CC) $(\varphi 5 \times 22 \mathrm{~cm}, \quad n$-hexane-EtOAc $=10: 1 \rightarrow 5: 1 \rightarrow 3: 1 \rightarrow 1: 1 \rightarrow$ $\left.\mathrm{CHCl}_{3}: \mathrm{MeOH}=10: 1 \rightarrow 7: 1 \rightarrow 5: 1 \rightarrow 3: 1 \rightarrow 2: 1 \rightarrow 1: 1\right)$ 를 실시하여 20 개의 분획물 (TME-1 TME-21)을 얻었다. 이 중에서 TME-10 $(1.1 \mathrm{~g})$ 분획에 대하여 $\mathrm{SiO}_{2} \mathrm{CC}\left(\varphi 4 \times 13 \mathrm{~cm}, \mathrm{CHCl}_{3}-\mathrm{MeOH}=\right.$ 7:1)를 실시하여, 17개의 분획물 (TME10-1 TME1-10-17)을 얻 었으며, 화합물 1 (quercetin, TME10-13(37), $53 \mathrm{mg}, \mathrm{Ve} / \mathrm{Vt}$ $0.614-0.705, \mathrm{R}_{\mathrm{f}}=0.56$ on $\mathrm{SiO}_{2}$ TLC $60 \mathrm{~F}_{254 \mathrm{~S}}, \mathrm{CHCl}_{3}-\mathrm{MeOH}-$ $\left.\mathrm{H}_{2} \mathrm{O}=7: 3: 1\right)$ 을 분리 하였다.
화합물 1 (quercetin): Yellow amorphous powder $\left(\mathrm{MeOH}-\mathrm{H}_{2} \mathrm{O}\right)$; m.p 232-234 $\left.{ }^{\circ} \mathrm{C} ;[\alpha]_{\mathrm{D}}=-11.8, \mathrm{c}=0.8, \mathrm{MeOH}\right) ;$ pos. $\mathrm{FAB} / \mathrm{MS}$ $m / z: 303[\mathrm{M}+1]^{+},{ }^{1} \mathrm{H}-\mathrm{NMR}\left(400 \mathrm{MHz}, \mathrm{CD}_{3} \mathrm{OD}, \delta_{\mathrm{H}}\right): 6.30(1 \mathrm{H}$, d, $J=1.6 \mathrm{~Hz} \mathrm{H}-6), 6.54(1 \mathrm{H}, \mathrm{d}, J=1.6 \mathrm{~Hz}, \mathrm{H}-8), 7.01(1 \mathrm{H}, \mathrm{d}$ $\left.J=8.4 \mathrm{~Hz}, \mathrm{H}-5^{\prime}\right), 7.69\left(1 \mathrm{H}\right.$, dd. $\left.J=8.4,2.0 \mathrm{~Hz}, \mathrm{H}-6^{\prime}\right), 7.80$ $\left(1 \mathrm{H}, \mathrm{d}, \quad J=2.0 \mathrm{~Hz}, \mathrm{H}-2^{2}\right), 12.16 \quad(1 \mathrm{H}, \mathrm{s}, \mathrm{OH}-5) ;{ }^{13} \mathrm{C}-\mathrm{NMR}$ $\left(100 \mathrm{MHz}, \mathrm{CDCl}_{3}, \ddot{a}_{\mathrm{C}}\right): 177.05$ (C-4), 165.26 (C-7), 163.14 (C-5), 157.03 (C-9), 148.78 (C-4'), 147.85 (C-2), 146.56 (C- 
(A)

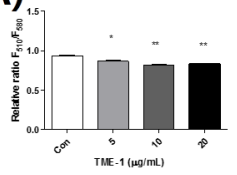

(B)

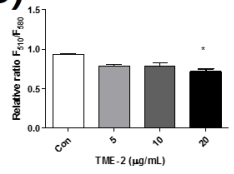

(C)

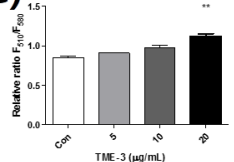

(D)

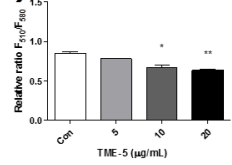

(E)

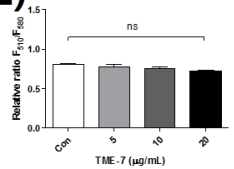

(F)

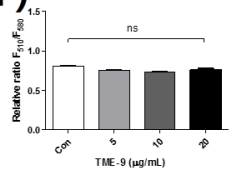

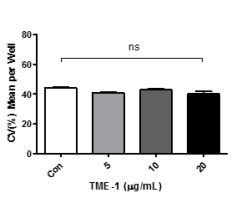

(G)

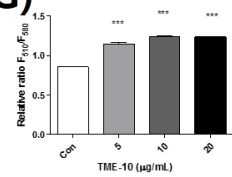

(H)
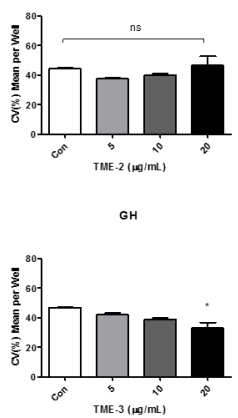

GH

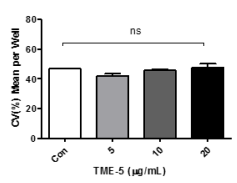

$\mathrm{GH}$

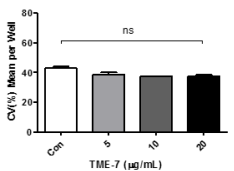

eH

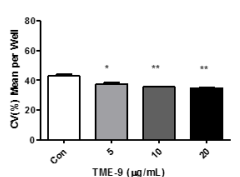

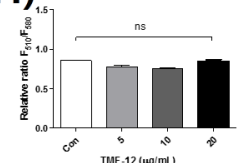

(I)

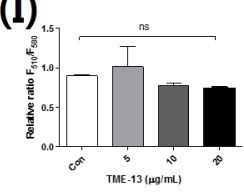

(J)

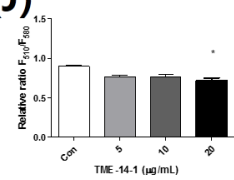

(K)

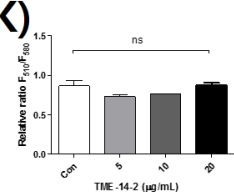

(L),

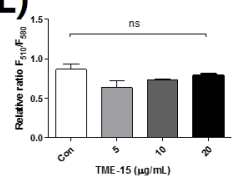

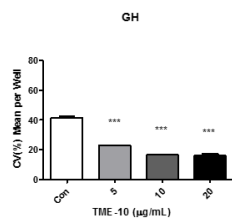

(M)
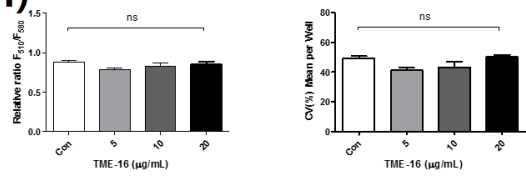

GH

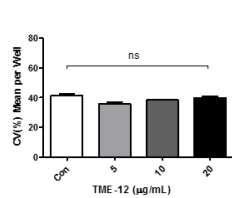

(N)
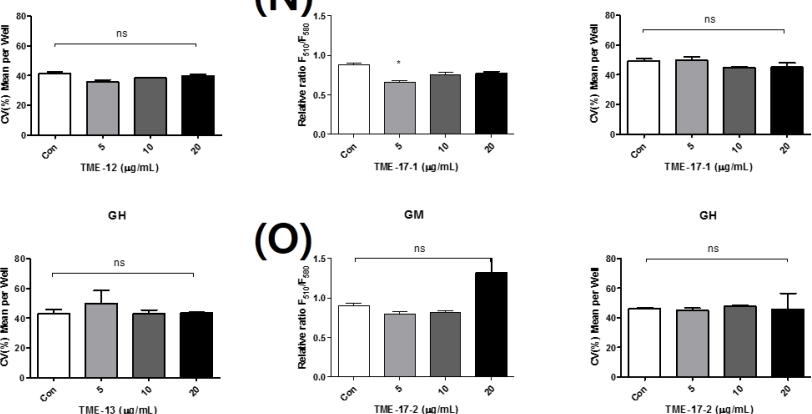

(O)
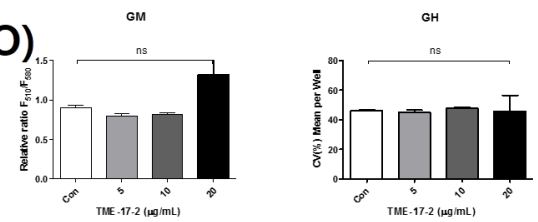

(P)
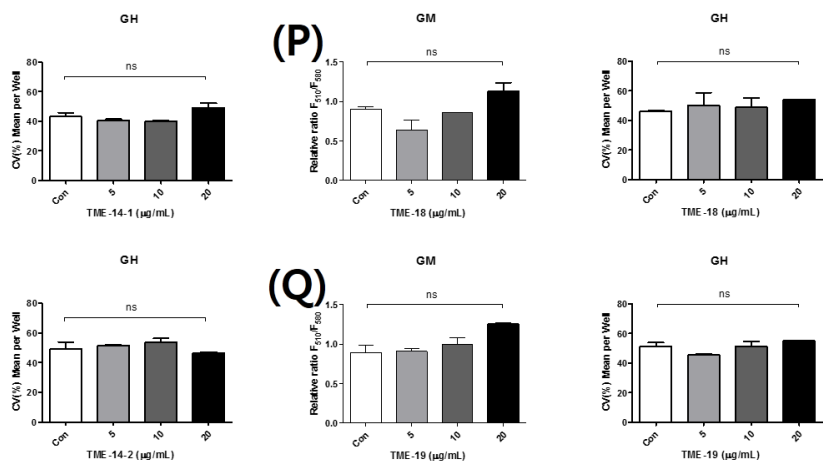

(R)
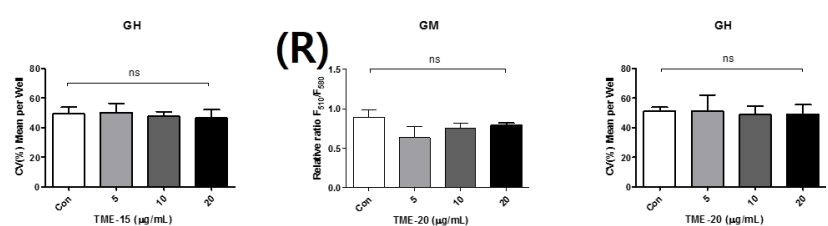

(S)
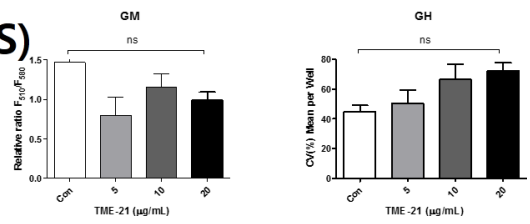

Fig. 4 Evaluation of antioxidative activity using GM and GH after treatment with 21 frations of EtOAc (TME) fraction from tomato extract. GSH recovery capacity assay of 21 frations of TME were performed in concentration dependent manner. Results are presented as mean \pm SEM. $* p \leq 0.05$, $* * p \leq 0.01, * * * p \leq 0.001$ compared with control. Con: non-treated (control) group

3'), 137.62 (C-3), 125.83 (C-10), $121.91\left(\mathrm{C}-1^{\prime}\right), 116.34\left(\mathrm{C}-5^{\prime}\right)$ 116.17 (C-2'), 104.27 (C-10), 99.56 (C-6), 94.95 (C-8)

\section{결과 및 고찰}

토마토 (Lycopersicon esculentum) 추출, 분흭물에서의 항산화 능 평가

토마토 추출물의 항산화 활성을 알아보기 위해 $\mathrm{hUC}-\mathrm{MSC}$ 에 추
출물을 $5,10,20 \mu \mathrm{g} / \mathrm{mL}$ 농도 별로 처리하여 $\mathrm{GSH}$ 회복능을 비교하였다(Fig. 2). 추출물을 처리하지 않은 대조군과 비교했을 때, 토마토추출물은 $5 \mu \mathrm{g} / \mathrm{mL}$ 농도에서 $\mathrm{GM} 1.16 \pm 0.02$ 로 대조군 $(0.68 \pm 0.03)$ 대비 $70.6 \%$ 의 증가를 보였다. 또한, $\mathrm{GH}$ 도 같은 농 도에서 $29.96 \pm 0.06$ 으로 대조군 $(50.37 \pm 2.79)$ 대비 $40.5 \%$ 감소하 여 높은 GSH 회복능을 나타내었다. 그 이상의 농도에서도 모 두 유의미한 $\mathrm{GM}$ 의 증가와 $\mathrm{GH}$ 의 감소가 유지되었다(Fig. 2). 이러한 결과를 토대로, 토마토 추출물이 세포 내 항산화능 활 성에 도움을 주는 것을 확인하였으며, 본 농도 범위를 추가적 
(A)

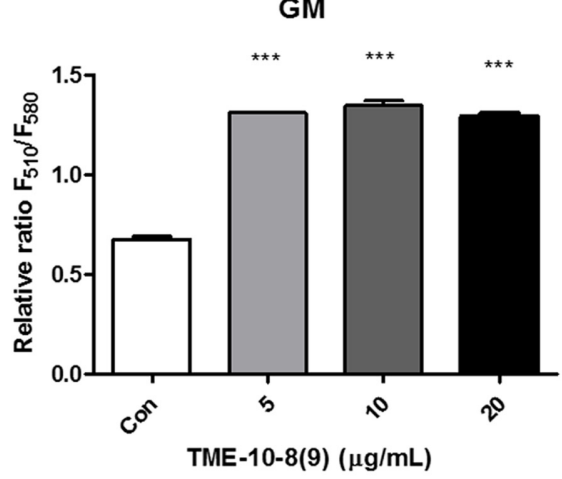

(B)

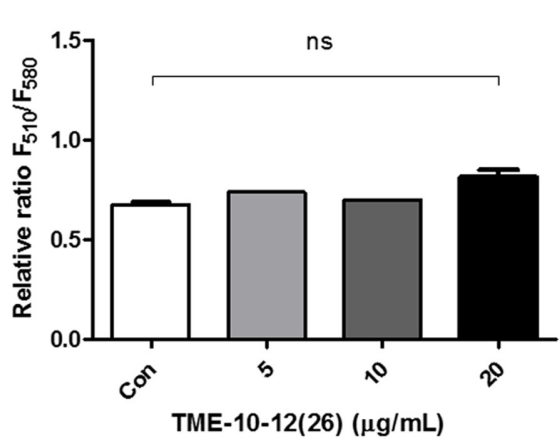

(C)

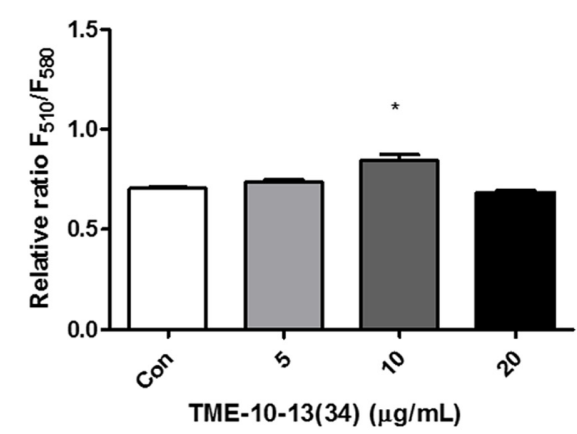

(D)

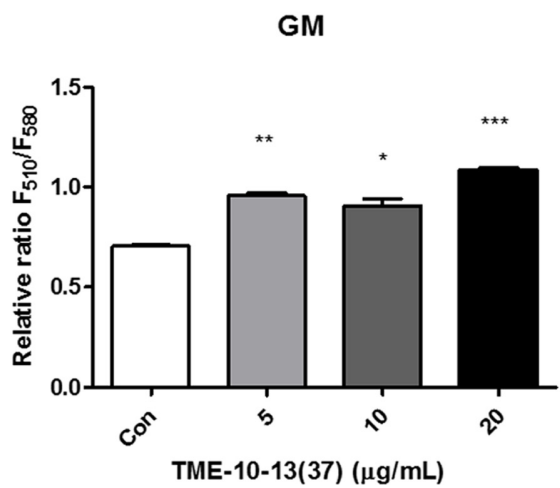

GH

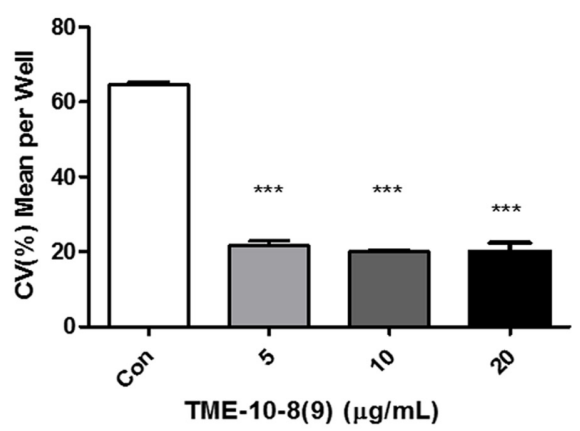

GH

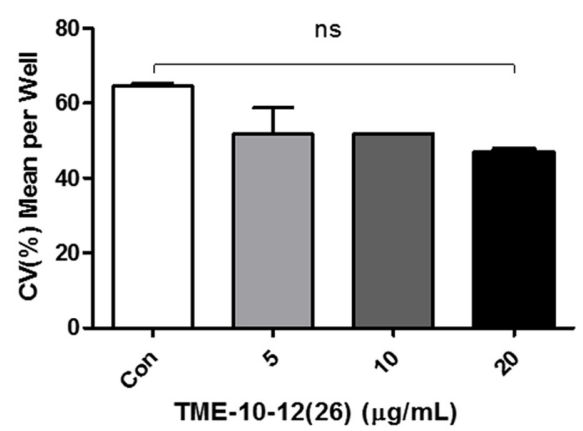

GH

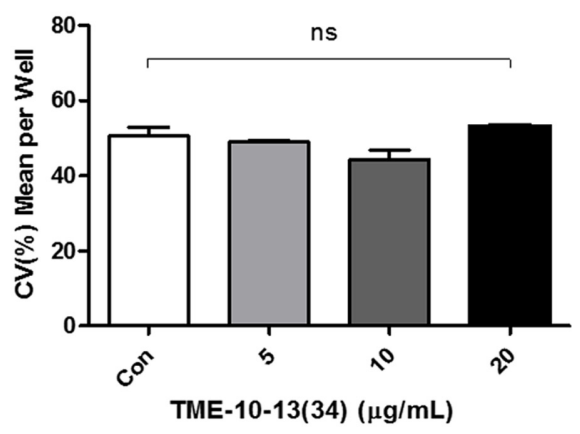

GH

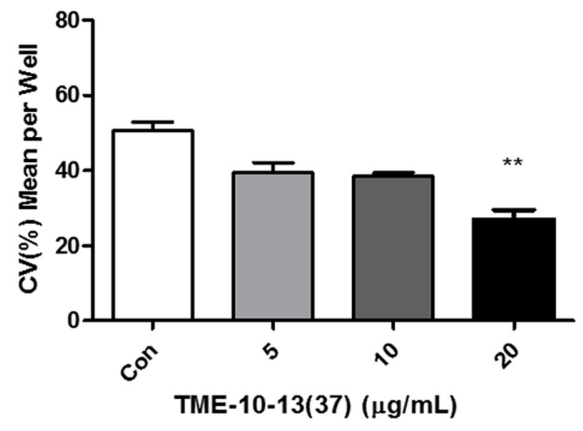

Fig. 5 Evaluation of antioxidative activity using GM and GH after treatment with 4 frations of TME-10 from tomato extract. GSH recovery capacity assay of 4 frations of TME- 10 were performed in concentration dependent manner. Results are presented as mean $\pm \operatorname{SEM} .{ }^{*} p \leq 0.05,{ }^{* *} p \leq 0.01$, $* * * p \leq 0.001$ compared with control. Con: non-treated (control) group 

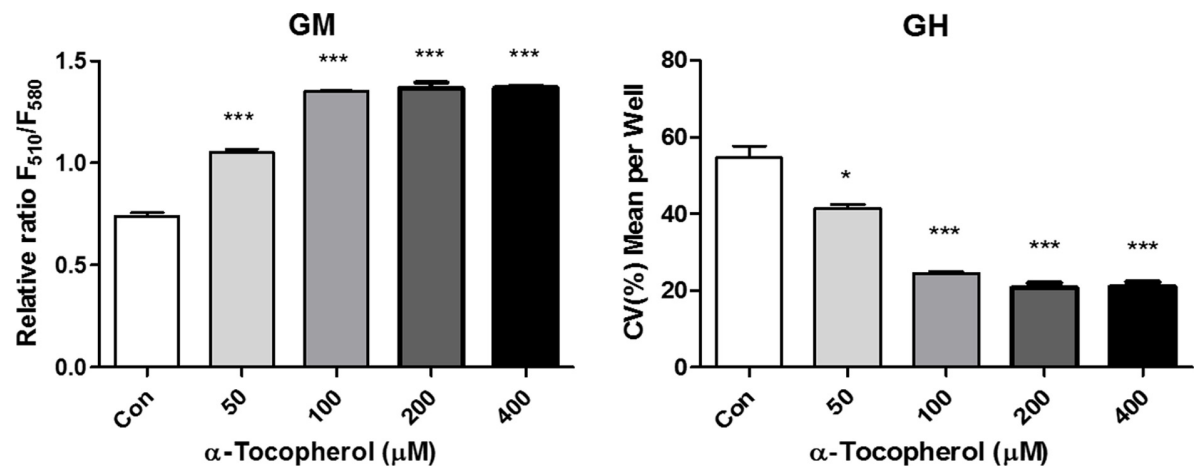

Fig. 6 Evaluation of antioxidative activity using GM and GH after treatment with $\alpha$-Tocopherol. GSH recovery capacity assay of $\alpha$-Tocopherol was performed in concentration dependent manner. Results are presented as mean \pm SEM. ${ }^{*} p \leq 0.05,{ }^{* * *} p \leq 0.001$ compared with control. Con: non-treated (control) group

인 실험에도 적용하였다.

토마토에서 항산화능을 가지는 화합물을 탐색하기 위해 추가 적인 추출 공정을 통하여 극성차이를 이용한 $\mathrm{EtOAc}$ 층, $n-\mathrm{BuOH}$ 층, $\mathrm{H}_{2} \mathrm{O}$ 층으로 계통분획을 진행하여 $\mathrm{TME}, \mathrm{TMB}, \mathrm{TMH}$ 의 분 획물을 얻은 뒤에 $\mathrm{TME}, \mathrm{TMB}$ 분획물의 $\mathrm{GSH}$ 회복능을 평가하 였다. $\mathrm{TMB}$ 의 경우, $20 \mu \mathrm{g} / \mathrm{mL}$ 농도를 처리한 실험군은 $\mathrm{GM}$ $1.09 \pm 0.02$ 로 대조군 $(0.89 \pm 0.04)$ 대비 $22.5 \%$ 의 증가를 보였으나 통계적으로 유의미한 차이로 나타나지 않았고, $\mathrm{GH}$ 에서는 $5 \mu \mathrm{g}$ / $\mathrm{mL}$ 만 처리해도 $39.31 \pm 0.26$ 으로 대조군 $(58.90 \pm 1.51)$ 대비 $33.3 \%$ 감소하여 세포 간의 균질성이 향상되는 것을 확인하였다(Fig. 3). $\mathrm{TME}$ 는 $20 \mu \mathrm{g} / \mathrm{mL}$ 농도를 처리한 실험군에서 $\mathrm{GM} 1.29 \pm$ 0.02 로 대조군 $(0.89 \pm 0.04)$ 대비 $44.9 \%$ 의 증가를 보였고, $\mathrm{GH}$ 에 서는 $\mathrm{TMB}$ 와 마찬가지로 $5 \mu \mathrm{g} / \mathrm{mL}$ 만 처리해도 $40.23 \pm 0.38$ 로 대

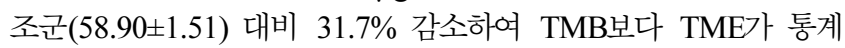
적인 차이를 보이며 더 $\mathrm{GSH}$ 회복능을 향상시키는 것으로 나 타났다 (Fig. 3).

$\mathrm{TME}$ 층으로부터 $\mathrm{SiO}_{2} \quad \mathrm{CC}(\varphi 5 \times 22 \mathrm{~cm}, n$-hexane-EtOAc $10: 1 \rightarrow 5: 1 \rightarrow 3: 1 \rightarrow 1: 1 \rightarrow \mathrm{CHCl}_{3}: \mathrm{MeOH}=10: 1 \rightarrow 7: 1 \rightarrow 5: 1 \rightarrow$ $3: 1 \rightarrow 2: 1 \rightarrow 1: 1$ )를 실시하여 21개의 분획물(TME-1 TME-21)을 얻어 상기 실험방법과 동일하게 $\mathrm{GSH}$ 회복능을 평가하였다. 먼 저, TME-7, TME-12, TME-13, TME-14-1, TME-14-2, TME15, TME-16, TME-17-2, TME-18, TME-19, TME-20, TME21 그룹에서는 어떠한 처리농도에서도 추출물을 처리하지 않은 대조군 대비 유의적인 변화가 나타나지 않았다(Fig. 4). 또한, TME-1, TME-2, TME-5, TME-17-1 그룹에서는 특정 처리농도 에서 대조군 대비 $\mathrm{GSH}$ 회복능이 감소되었다. TME-1은 처리농 도 $5 \mu \mathrm{g} / \mathrm{mL}$ 에서 $\mathrm{GM} \quad 0.87 \pm 0.01$ 로 대조군 $(0.94 \pm 0.01)$ 대비 $7.4 \%$ 감소하는 경향이 보였고, TME-2는 처리농도 $20 \mu \mathrm{g} / \mathrm{mL}$ 에 서 $\mathrm{GM} 0.71 \pm 0.04$ 로 대조군 $(0.94 \pm 0.01)$ 대비 $24.5 \%$ 감소했다. 또한, TME-5는 처리농도 $10 \mu \mathrm{g} / \mathrm{mL}$ 에서 $\mathrm{GM} 0.67 \pm 0.03$ 으로 대 조군 $(0.85 \pm 0.02)$ 대비 $21.2 \%$ 감소, $\mathrm{TME}-17-1$ 은 처리농도 5 $\mu \mathrm{g} / \mathrm{mL}$ 에서 $\mathrm{GM} \quad 0.66 \pm 0.02$ 로 대조군 $(0.88 \pm 0.02)$ 대비 $25 \%$ 감 소하는 결과를 얻었다(Fig. 4). TME-9의 경우는 처리농도 $5 \mu \mathrm{g}$ / $\mathrm{mL}$ 부터 $\mathrm{GM}$ 의 유의적인 변화는 없이 $\mathrm{GH} 37.58 \pm 0.83$ 으로 대조 군 $(43.00 \pm 1.02)$ 대비 $12.6 \%$ 감소하여 세포 간의 균질성이 향상 되는 것을 확인하였다(Fig. 4). 마지막으로, TME-3와 TME-10 그룹은 특정 처리농도에서 대조군 대비 GSH 회복능이 향상되
었다. TME-3는 처리농도 $20 \mu \mathrm{g} / \mathrm{mL}$ 에서 $\mathrm{GM} 1.12 \pm 0.03$ 으로 대 조군 $(0.85 \pm 0.02)$ 대비 $31.8 \%$ 증가했고, $\mathrm{GH}$ 도 같은 농도에서 $33.01 \pm 3.71$ 로 대조군 $(46.97 \pm 0.06)$ 대비 $29.7 \%$ 감소하였다. $\mathrm{TME}-10$ 의 경우, 처리농도 $5 \mu \mathrm{g} / \mathrm{mL}$ 에서 $\mathrm{GM} 1.15 \pm 0.02$ 로 대조 군 $(0.86 \pm 0.00)$ 대비 $33.7 \%$ 증가했고, $\mathrm{GH}$ 도 같은 농도에서 $22.99 \pm 0.13$ 으로 대조군 $(41.31 \pm 1.21)$ 대비 $44.3 \%$ 감소하여 높은 GSH 회복능을 나타내었다 (Fig. 4).

상기의 결과를 통하여 TME-10 분획물이 적은 농도를 처리 해도 세포 내 $\mathrm{GSH}$ 회복능을 향상시키는 데에 도움을 준다는 것을 발견하였다. 이를 바탕으로 TME-10 (1.1 g) 분획에 대하 여 $\mathrm{SiO}_{2} \mathrm{CC}\left(\varphi 4 \times 13 \mathrm{~cm}, \mathrm{CHCl}_{3}: \mathrm{MeOH}=7: 1\right)$ 를 실시하여, 17 개 의 분획물 (TME-10-1 TME-10-17)을 얻었다. 이중 TME-10-8 (9), TME-10-12 (26), TME-10-13 (34), TME-10-13 (37)의 4 가지 분획물로부터 항산화 활성을 조사하였다. 활성시료 분획물 을 동일한 방법으로 GSH 회복능을 측정하였다. TME-10-8 (9) 의 경우, 처리농도 $5 \mu \mathrm{g} / \mathrm{mL}$ 에서 $\mathrm{GM} 1.31 \pm 0.00$ 으로 대조군 $(0.68 \pm 0.01)$ 대비 $92.6 \%$ 증가했고, $\mathrm{GH}$ 도 같은 농도에서 21.78 \pm 1.10 으로 대조군 $(64.49 \pm 0.76)$ 대비 $66.2 \%$ 감소하여 비교 그룹 중 가장 높은 $\mathrm{GSH}$ 회복능을 나타내었다. TME-10-12 (26) 분 획물은 어떠한 처리농도에서도 추출물을 처리하지 않은 대조군 대비 유의적인 변화가 나타나지 않았으며, TME-10-13 (34)는 처리농도 $10 \mu \mathrm{g} / \mathrm{mL}$ 에서 $\mathrm{GM} 0.85 \pm 0.03$ 으로 대조군 $(0.71 \pm 0.00)$ 대비 $19.7 \%$ 증가하는 경향을 보였다. 마지막으로, TME-10-13 (37)은 처리농도 $5 \mu \mathrm{g} / \mathrm{mL}$ 에서 $\mathrm{GM} \quad 0.96 \pm 0.02$ 로 대조군 $(0.71 \pm$ 0.00 ) 대비 $35.2 \%$ 증가했고, $\mathrm{GH}$ 는 처리농도 $20 \mu \mathrm{g} / \mathrm{mL}$ 에서 $26.95 \pm 2.59$ 으로 대조군 $(50.73 \pm 2.15)$ 대비 $46.9 \%$ 감소하여 비교 그룹 중 두번째로 높은 GSH 회복능을 나타내었다(Fig. 5).

\section{활성물질 동정}

항산화 활성이 높았던 TME-10-13 (37) 분획에 대하여 NMR, $\mathrm{IR}, \mathrm{FAB} / \mathrm{MS}$ 를 측정하여 구조동정을 실시하였다. 화합물 1 은 대 표적인 flavonol 화합물로 TLC 확인시 UV $(254 / 365 \mathrm{~nm})$ 에서 강한 UV 흡수를 보였으며, $10 \%$ 황산 발색 시 노란색으로 발 색 되었다. Negative $\mathrm{FAB} / \mathrm{MS}$ 에서 $m / z 301[\mathrm{M}-\mathrm{H}]^{-}$분자이온 peak가 관측되어 분자량을 302 로 확인하였다. IR spectrum으 로부터 공역화된 카보닐기 $\left(1615 \mathrm{~cm}^{-1}\right)$, 수산기 $\left(3355 \mathrm{~cm}^{-1}\right)$ 와 이 중결합 $\left(1584 \mathrm{~cm}^{-1}\right)$ 이 있는 것으로 확인되었다. ${ }^{1} \mathrm{H}-\mathrm{NMR}$ (400 
$\left.\mathrm{MHz}, \mathrm{CD}_{3} \mathrm{OD}, \delta_{\mathrm{H}}\right)$ spectrum에서 3개의 olefin methine proton signal $7.80\left(1 \mathrm{H}, \mathrm{d}, J=2.0 \mathrm{~Hz}, \mathrm{H}-2^{\prime}\right), 7.69(1 \mathrm{H}, \mathrm{dd} . \quad J=8.4$, $\left.2.0 \mathrm{~Hz}, \mathrm{H}-6^{\prime}\right), 7.01\left(1 \mathrm{H}, \mathrm{d} J=8.4 \mathrm{~Hz}, \mathrm{H}-5^{\prime}\right)$ 를 통해 $1,2,4-$ trisubstituted benzene 구조가 존재함을 예상하였다. 또한 2개의 olefin methine proton signal $6.54(1 \mathrm{H}, \mathrm{d}, J=1.6 \mathrm{~Hz}, \mathrm{H}-8)$, $6.30(1 \mathrm{H}, \mathrm{d}, J=1.6 \mathrm{~Hz}, \mathrm{H}-6)$ 을 통해 1,2,3,5-tetrasubstituted benzene 구조가 존재함을 예상하였다. 이를 통해 이 화합물이 flavonol 화합물임을 예상하였다. ${ }^{13} \mathrm{C}-\mathrm{NMR}\left(100 \mathrm{MHz}, \mathrm{CD}_{3} \mathrm{OD}\right.$, $\left.\delta_{\mathrm{C}}\right)$ spectrum에서 탄소수가 15 개임을 확인하였고, 이를 통해 flavonol임을 확인하였다. 1개의 conjugated ketone carbon signal $\left(\delta_{\mathrm{C}} 177.05\right), 7$ 개의 oxygenated olefin quaternary carbon signal $\left(\delta_{\mathrm{C}} 165.26 ; 163.14 ; 157.03 ; 148.78 ; 147.85 ; 146.56\right.$; 137.62)을 확인하였고, 2 개의 olefin quaternary carbon signal $\left(\delta_{\mathrm{C}} 125.83 ; 121.91\right)$ 을 확인하였으며, 5 개의 olefin methine carbon signal $\left(\delta_{\mathrm{C}} 116.34 ; 116.17 ; 104.27\right.$; 99.56; 94.95)을 확 인하였다. 위의 data 를 문헌값[9,10]과 비교하여 화합물 $\mathbf{1}$ 을 3',4',5,7-tetrahydroxyflavonol, quercetin 으로 구조 동정 하였다.

Quercetin 은 다양한 문헌에서 항산화 활성, 항염 활성, 미백 활성[18] 등이 보고되어 있다. 따라서 토마토 추출물과 분획물 에서의 높은 GSH 회복능 또한 주요화합물 중 하나인 quercetin 에 의한 영향이 있음을 알 수 있다. 또한, 이와 같은 결과로 토 마토가 항산화능을 가지는 건강식품소재로서 사용할 수 있는 가 능성을 확인하였다.

\section{초 록}

토마토 액상을 $70 \% \mathrm{MeOH}$ 수용액으로 추출하고, 얻어진 추출 물을 EtOAc, $n-\mathrm{BuOH}$ 및 물로 용매 분획 하였다. 이 중 활성 이 확인된 EtOAc 분획으로부터 활성을 측정해 가며 silica gel 과 octadecyl silica gel column chromatography로 정제하여 1 종의 화합물을 분리 하였다. 화합물의 화학구조는 nuclear magnetic resornance, mass spectroscopy 및 infrarad spectroscopy 등의 스텍트럼 데이터를 해석 하여 quercetin (1)으로 동정 하 였다. 본 연구를 통해서 glutathione mean의 증가와 glutathione heterogeneity의 감소를 보인 토마토 분획물이 세포 내 glutathione 수준을 균일하게 올려준다는 것을 입증함으로써 항 산화 효능을 확인할 수 있었다.

Keywords 토마토 · 회복능 · Glutathione · Quercetin

\section{References}

1. Aneta G, Małgorzata MD (2014) Lycopene-antioxidant with radioprotective and anticancer properties. A review. Rocz Panstw Zakl Hig 65(4): 263271

2. Jung EB, Shin MK (1990) In Hyang Yak DaeSaJun. 3rd edition. Young Lim Sa: Seoul

3. Wu G, Fang YZ, Yang S, Lupton RJ, Turner DN (2004) Glutathione metabolism and its implications for health. J Nutr 134(3): 489-492

4. Mailloux RJ, McBride SL, Harper ME (2013) Unearthing the secrets of mitochondrial ROS and glutathione in bioenergetics. Trends Biochem Sci 38(12): 592-602

5. Yang SL, Yu PL, Chung KR (2016) The glutathione peroxidasemediated reactive oxygen species resistance, fungicide sensitivity and cell wall construction in the citrus fungal pathogen Alternaria alternata. Environ Microbiol 18(3): 923-935

6. Townsend DM, Tew KD, Tapiero H (2003) The importance of glutathione in human disease. Biomed Pharmacother 57(3-4): 145-155

7. Jeong EM, Yoon JH, Lim J, Shin JW, Cho AY, Heo J, Lee KB, Lee JH, Lee WJ, Kim HJ, Son YH, Lee SJ, Cho SY, Shin DM, Choi K, Kim IG (2018) Real-Time Monitoring of Glutathione in Living Cells Reveals that High Glutathione Levels Are Required to Maintain Stem Cell Function. Stem Cell Reports 10(2): 600-614

8. Jeong EM, Shin JW, Lim J, Kim JH, Kang H, Yin Y, Kim HM, Kim YH, Kim SG, Kang HS, Shin DM, Choi K, Kim IG (2019) Monitoring Glutathione Dynamics and Heterogeneity in Living Stem Cells. Int J Stem Cells 12(2):367-379

9. Keiko M, Mitsuko N, Misa N, Iknke T (2003) Inhibitory effect of quercetin on carrageenan-induced inflammation in rats. Life Sciences 74 : 709-721

10. Akito N, Tomochika S, Yoshiko M, Harumi O, Jinsaku S, Hajime M (1975) Antioxidants from Rape (Brassica campestris VIR. Japonica Hara) oil cake. Nat Prod Res 18(3): 231-239

11. Meister A, Anderson ME (1983) Glutathione. Annu Rev Biochem 52: 711-760

12. Winterbourn CC, Hampton MB (2008) Thiol chemistry and specificity in redox signaling. Free Radic Biol Med 45(5): 549-561

13. Montserrat M, Albert M, Anna C, Carmen GR, Neil K, José C FC (2013) Mitochondrial glutathione: features, regulation and role in disease. Biochim Biophys Acta 1830(5): 3317-3328

14. Dinesha R, Thammannagowda SS, Shwetha KL, Prabhu MSL, Madhu CS, Leela S (2014) The antioxidant and DNA protectant activities of Star Anise (Illicium verum) aqueous extracts. J Pharmacogn Phytochem 2(5): 98-103

15. Kim EJ, Choi JY, Yu MR, Kim MY, Lee SH, Lee BH (2012) Total Polyphenols, Total Flavonoid Contents, and Antioxidant Activity of Korean Natural and Medicinal Plants. Korean Society of Food Science and Technology 44(3): 337-342

16. Dai DF, Chiao YA, Marcinek DJ, Szeto HH, Rabinovitch PS (2014) Mitochondrial oxidative stress in aging and healthspan. Longev Healthspan 3: 6

17. de la Asuncion JG, Millan A, Pla R, Bruseghini L, Esteras A, Pallardo FV, Sastre J, Vina J (1996) Mitochondrial glutathione oxidation correlates with age-associated oxidative damage to mitochondrial DNA. FASEB J 10(2): 333-338

18. Wang L, Tu YC, Lian TW, Hung JT, Yen JH, Wu MJ (2006) Distinctive antioxidant and antiinflammatory effects of flavonols. J Agri Food Chem 54(26):9798-9804 